\title{
The governmentality of journalism education in Ghana
}

\author{
Wincharles Coker \\ Lecturer \\ Department of Communication Studies \\ University of Cape Coast, Ghana \\ E-mail:wcoker@ucc.edu.gh
}

Submitted: May 8, 2017 / Accepted: January 18, 2018 / June 8, 2018

\begin{abstract}
This study evaluates the role of two state regulatory regimes in shaping journalism education at a public university in Ghana. Focusing on the mandates of the National Council for Tertiary Education (NCTE) and the National Accreditation Board (NAB), the work demonstrates how these institutions monitor, evaluate and shape the curriculum of the undergraduate program in communication studies at the University of Cape Coast. Based on Foucault's concept of governmentality, the paper shows that the journalism program designed by both faculty and state regulatory regimes for the University of Cape Coast, as in many other universities in sub-Saharan Africa, is still primarily focused on media-centric, developmentalist and instrumentalist approaches, and pays little attention to critical theory and transcultural aesthetics. The fusion of these theoretical perspectives into the communication education curriculum is crucial for empowering students to unmask practices that perpetuate social inequality, dominance, power asymmetry and hegemony in society in order to transform it in positive ways.
\end{abstract}

Keywords: governmentality, journalism education, power, regimes of control, university

\section{Introduction}

This paper evaluates the role the state as the chief sponsor of higher education plays in shaping journalism education at the University of Cape Coast (UCC), Ghana, an institution established in 1962 by Ghana's first president Kwame Nkrumah. The work interrogates how the government of Ghana, through its regimes of control, exercises its authority over the means of production in the academy. The paper examines the political economy within which higher education works in the country, focusing on the mandates of two of its bodies: the National Council for Tertiary Education(NCTE) 
and the National Accreditation Board (NAB). My overarching goal is to deconstruct how these systems of control monitor, evaluate, and shape the knowledge economy in communication education at UCC's Department of Communication Studies, birthed in 2010.

This work fills an important gap in the literature on governmentality studies in higher education, in general and journalism education, in particular, in sub-Saharan Africa. Existing works on the subject have focused on Anglo-American perspectives (Peters et al., 2009). For instance, Gorman's (2012) critical analysis of the National Survey of Student Engagement (NSSE) examined the power relations shaping the directions and practices of higher education in twenty-first century America. The author observed that the existing milieu of accountability is primarily dominated by the neoliberal assumption that higher education works best when governed by market forces alone. For Gorman (2012), this assumption reduces higher education to a market-mediated private good and thus erodes the virtues of higher education as one that enables students to receive a broad education, contributes to knowledge for the public good and empowers students to become society's critics and social conscience.

Sadly, the subject of governmentality in Africa's journalism education is under-studied. Despite the burgeoning literature on the subject, little is known about the role governmental agencies play in regulating journalism education on the African continent as is exemplified in the current work by Goodman and Steyn's (2017) Global Journalism Education in the 21st Century. The volume contains reports of only two countries in Africa, namely South Africa and Egypt. There is, however, an expansive body of works on professionalism and professional identity (Aldridge \& Evetts, 2003; Bossio, 2011). For instance, Diedong's (2008) newsroom study of two newspapers in Ghana has shown that Ghanaian journalists aim to be guided by their belief in their code of ethics, honesty, transparency, and cooperation with their media organization; a clear idea of human rights and commitment to uphold them; courage in the face of threats of the powerful; and personal convictions of right and wrong. Yet professional standards 
in Africa, Ogundimu, Oyewo and Adegeke (2010) have observed, are low due to serious challenges confronting journalism education in the sub-region. These include lack of quality and rigor, poor sequencing of the curricula, and little focus on practical internships. I agree with Boafo (1988) that journalistic standards in sub-Saharan Africa can be improved if the conditions of service of journalists and the technical resources they work with are also improved. This means that journalists should be prepared to exhibit professional performance worthy of enhanced social recognition and prestige. Boafo (1988) also noted that African governments should promote quality journalism education by creating and maintaining a congenial political climate for the profession to thrive. Nonetheless, the crucial role African governments need to play to promote quality journalism education on the continent lacks serious scrutiny in the literature. This paper attempts to do so by evaluating how regulatory regimes that supervise higher education in Ghana shape the work of communication educators at the University of Cape Coast.

The rest of the paper is organized into six sections. The first succinctly discusses the idea of governmentality as the conceptual framework undergirding the work. Next I contextualize the study through an overview of journalism education in sub-Saharan Africa and survey the political economy of higher education in Ghana. The third strand takes a critical look at the political superstructure, composition and functions of Ghana's NTCE and NAB, and more important, how contemporary bureaucratization and corporatization give meaning to learning and the exercise of intellectual freedom in Ghana. Some scholars have argued that the grand narratives of economics have led to the crisis of the university and have compromised its self-critical nature (Bert, 2011). The fourth section explores how the systems of control and accountability supervised mainly by NAB have shaped the curriculum design of UCC's Bachelor of Arts degree in Communication Studies. I will demonstrate that the program is based on media-centric, instrumentalist and developmentalist philosophies that pay little attention to critical theory and aesthetics of transculturalism. The 
fifth and sixth strands make recommendations and conclude the paper, focusing on the fusion of critical theories in the curricula of journalism education in Ghana and suggest the adoption of transcultural aesthetics as an approach to negotiate change and diversity in the field.

\section{Governmentality as a concept}

Governmentality is concerned with the art of governance, or more specifically, how people are made governable through the examination of their conduct (Chamberlain, 2014). The concept was developed by the French philosopher Michel Foucault to analyze the operation of governmental power, the techniques and practices by which it works and the rationalities and strategies invested in it (Foucault, 1997). Governmentality thus encourages the examination of how power in different groups, organizations and institutions operates subtly and on multiple levels to influence the behavior of a population (Miller \& Rose, 2008). The goal of the examination, Foucault (1997) wrote, is to instill discipline and responsibility in the governed. This is often achieved through systems of technology and instrumentality, evaluation, monitoring and calculation. Governmentality is, therefore, a technology of power because it examines practices of governance based on their methods and objects of control (Gorman, 2012).

Although Foucault identified sovereignty as a vital form of power, his writings focused more on capillary power, or rather, the taken-for-granted manifestations of power in state institutions such as the prison, school and hospital. With Bentham's idea of the "Panopticon" as his guide, Foucault (1995) wrote in Discipline and Punish, in particular, that the primary function of institutions is to instill discipline, insist on conformity and alter behavior. He stressed that institutions act as panoptic apparatuses by performing two main tasks: (a) binary division and branding and (b) technologies of power. In the context of higher education, they control the granting of accreditation to both public and private tertiary institutions by creating a binary line between accredited colleges and nonaccredited colleges. As I will show in this work, the mechanism 
of differentiation ensures that regulatory bodies insist on quality assurance by checking poor standards of educational objectives. They also act as laboratories of power by acting as systems of ordered procedures for the production, regulation, distribution, circulation and operation of statements. Using legal and policy documents, sets of evaluation criteria and protocol of expectations, they punish and/or reward academic institutions that comply or do not comply with their instructions. As seats of authority guiding the functions of academic institutions and reporting them to government, all bodies under their supervision are in "a state of consciousness and permanent visibility that assures the automatic functioning of power" (Foucault, 1995, p. 201). The surveillance is totalizing in that it guarantees compliance even in the absence of it.

States thus are interested in the practices of tertiary institutions because they sponsor the programs of these institutions. Through agents, such as national accreditation boards, the state enables, supports, teaches, models and regulates higher education (Brandt, 1998, p. 166). Brandt argues that it is the sponsors who underwrite occasions of literacy learning and use, and therefore, it is they who set the terms for access to literacy. This power enables them to reward compliance. She writes, "Sponsors are a tangible reminder that literacy learning throughout history has always required permission, sanction, assistance [or] coercion" (p. 167). Obligations toward sponsors of literacy by universities run deep because the sponsors shape, and, to a large extent, affect what, why and how the academy ought to behave. For example, the government of Ghana, at the time of writing this paper, had placed a ban on employment in the nation's public tertiary institutions in response to conditions by the International Monetary Fund (IMF), despite constant complaints by university management to lift the ban. Often state sponsors insist that the regulatory regimes check constantly the relationship between higher education and development (Bailey, 2014). 


\section{Overview of journalism education in Africa}

Coker, W./ Legon Journal of the Humanities 29.1 (2018)

Journalism education in Africa, like many professional programs, is heavily dependent on Western scholarship. The Norwegian scholar Skjerdal (2012) has argued that "an important issue for any journalism program in Africa is the question of whether journalism should be taught according to an established Western tradition, or in a distinct African way" (p. 24). For Skjerdal, communication education in Africa appears to be in conflict with Africa's unique ontologies and epistemologies. This challenge may be attributed to the preference of many African scholars for Western models and the dearth of Afrocentric frameworks guiding communication education. Earlier works (e.g., Murphy \& Scotton, 1987; Boafo, 1988) critique a seeming contradiction by African scholars who criticize Western education and yet have been unable to develop their own home-grown models. Murphy and Scotton (1987) noted that despite efforts by the African Council on Communication Education (ACCE), the only continental organization of communication educators founded in 1976, the training of African communication experts continues to face a number of challenges. There are arguments over the form of training and the non-African domination of the program. By the mid-70s, much of the debate focused on the lack of relevance for Africa's development (Murphy $\&$ Scotton, 1987).

The training was fundamentally anchored on the idea of developmentalism. Ghana's first president, Kwame Nkrumah, for example, was committed to developing the country through a robust press education. This, he felt, was needed to mobilize the new Ghana toward a singular developmental agenda. Formal journalism, Boafo (1988) wrote, started in February 1959 with the establishment of Ghana Institute of Journalism (GIJ) in 1959. Its mandate was two-fold: to provide formal and systematic training in journalism and to foster development of an independent cadre of journalists to play an active role in the emancipation of the African continent (Boafo, 1988). In view of this ideological agenda, GIJ and the then School of Communication Studies (SCS) designed curricula targeted at the Ghanaian élite. Courses included-and 
still do-print and broadcast journalism, mass communication, communication research methods, public relations/advertising and social psychology. Today, besides these two training institutions, communication training in Ghana has experienced a massive explosion.

One thing, nonetheless, is certain about the curricula of some communication departments in Ghana. Ever since the overthrow of the first president, they appear not to be anchored on any "specially recognized state policy [that is] integrated into national development planning" (Boafo, 1988, p. 70). Boafo concluded that a new curriculum needed to be designed toward creating among journalists and teachers awareness and knowledge of the socio-cultural, economic and political realities of the rural environment. He urged scholars and curriculum designers to revise the content, style and structure of communication curricula in Ghana. Ansu-Kyeremeh's (2014) latter mapping of trending approaches to communication theories and methods of inquiry in Ghana is one such response to the call. The work advocates a fusion of indigenous Africanist thought systems into theoretical and methodological formulations of communication scholarship.

Earlier attempts at heeding Boafo's (1988) call, however, seem to have focused more on professionalism. This is why James (1990) urged colleagues not to blindly imitate the global culture of the journalistic profession because not all training from the West may be useful to the development of the African continent. He proposed that rather than simply teach print and broadcast journalism, more effort was required to contextualize these courses within development communication scholarship, which according to him, should be in touch with the grassroots. He also urged African communication educators to reconsider the quality of language education they give to their students. "An examination of the syllabuses of communication schools reveals that much of the language proficiency of journalists," he regretted, "is invariably left to general studies programs and writing skills and allowed to blossom through the writing of news and feature articles for the schools' newspapers or magazines which are issued 
at predetermined intervals" (p. 10). In his view, language training must focus on the receptive and expressive skills of learners to improve their communicative competence. This competence, he stressed, is crucial for communication students to deal with problems of structure, style, register and tone. James (1990) proposed that journalism schools in Africa should encourage local language proficiency.

There also is the question of the quality of training on the continent. For instance, with the exception of South Africa the syllabi of eastern and southern Africa emphasize the acquisition of skills in print and broadcast journalism, advertising and public relations. Boafo and Wete's (2002) sponsored work by the United Nations Scientific and Cultural Organization (UNESCO) shows that communication curricula across Africa face serious setbacks. These include a deficit of experienced faculty, low salaries and inadequacy of teaching and learning resources. In addition, many textbooks are written by foreigners, mostly from Europe and North America. The content of these publications, Boafo and Wete (2002) observed, bears little impact on the social, political, economic and cultural reality of many African countries. Concerns to rethink the nature of communication pedagogy in Africa are critical because they have implications for the quality of graduates the educational system trains. As the scholars noted, the central concern in curriculum development is the establishment of a consistent relationship between general goals, on the one hand, and specific objectives to guide teaching, on the other. The mode of evaluating content, the authors proposed, should be guided by the following questions: What is the purpose of knowledge? What should be the aim of communication training? What curriculum design will most effectively implement the fundamental goals of the profession and what content (knowledge) should all students learn?

Skjerdal (2012) recently proposed three models for teaching journalism that are rooted in the lived experiences of Africans. These are journalism for social change, communal journalism and journalism based on oral discourse. The first, he said, is used in Africa as a vehicle for national unity and a tool for breaking 
with the colonial past. It is a kind of revolutionary or advocacy journalism. Because of its nation-building ethos, this type of journalism, he posited, "endorses journalistic interventionism and rejects an objectivist epistemology" (p. 643). The second model, communal journalism, is rooted in the community and its core values. To Skjerdal, training based on communal journalism recognises that journalists are members of the local community, and that their professional identity is second to their communal identity. This model presupposes a specific ontology of being which places public interest over individual interest. The third model, oral discourse journalism, derives its impetus from what tends to be the romanticization of indigenous African communication practices. These include oral tradition and folk culture (e.g., communal storytellers, musicians, poets and dancers). In addition to Skjerdal's models, I propose, just as Ansu-Kyeremeh (2014), communication education should be strongly rooted in the ontologies, epistemologies and hermeneutics of African societies.

\section{The political economy of higher education in Ghana}

Higher education in Ghana is mainly financed by the Ministry of Education, the Ghana Education Trust Fund, funds generated internally by tertiary institutions and international donors (Somuah, 2008). Over the last decade, the sector has witnessed significant growth in various aspects. These include widening access and participation, expansion of academic facilities, a transformative policy environment and innovative funding approaches to increase the financial sustainability of institutions (Atuahene \& Owusu-Ansah, 2013). According to Edu-Buandoh (2010), Ghanaian public universities "were all fashioned on the University of London structure," and were made to focus "on liberal courses and a few technical and professional courses" (pp. 59-60). Edu-Buandoh's (2010) thesis is that university education in Ghana began as a foreign intervention. What appears to be different in many public universities in Ghana today, than it was in the early years of a post-independent Ghana, she stressed, is the gradual shift from liberal programs to technical/vocational education. This new 
focus required that the government make university education a lot more accessible.

The government of Ghana issued a white paper in 1991 to reform tertiary education by the University Rationalization Committee (URC). Following the recommendations of the URC and the subsequent government white paper on the report, three regulatory agencies were established. These are the National Council for Tertiary Education (NCTE), the National Accreditation Board (NAB) and the National Board for Professional and Technician Examinations (NABPTEX) (Atuahene \& Owusu-Ansah, 2013). Universities in Ghana are empowered to set their own priorities for academic programming, curriculum content and structure, teaching philosophy and research agenda subject to requirements by the National Accreditation Board (NAB) and the National Council for Tertiary Education (NCTE). The type and nature of academic programs are, however, restricted by the law establishing the university, NCTE guidelines for program introduction and by accreditation (Gondwe \& Walenkamp, 2011).

The next sections explore the panoptic role of the NCTE and NAB and go on to demonstrate how their supervisory powers shape the work of communication educators in Ghana.

\section{The National Council for Tertiary Education of Ghana: Structure and mandate}

The National Council for Tertiary Education (NCTE) is the brainchild of the Ministry of Education, the government body in charge of tertiary education in Ghana. It was established by Act 454 of 1993 of the Parliament of the Fourth Republic of Ghana. As the sector with a huge portfolio comprising policy, planning and monitoring, the ministry took prudent steps to empower the NCTE to "deal with specific issues such as salary problems or the use of internally generated funds" (Bailey, 2014, p. 6) for tertiary institutions in the country. According to Bailey (2014), the establishment was modeled on the UK University Grants' Committee, a funding agency. She reports that the Council receives $95 \%$ of its funding from the government, all of which is allocated 
Coker, W./ The governmentality of journalism education in Ghana

to the Secretariat and the remaining $5 \%$ of its operational costs is covered by contributions from tertiary institutions. NCTE also has the responsibility to act as a "buffer" between the government and tertiary education institutions, especially in respect of academic freedom and autonomy of institutions. Table 1 specifies the core functions the Council performs in supervising the activities of funded public tertiary institutions under its watch. 
Table 1: Core functions of the National Council for Tertiary Education

\begin{tabular}{|c|c|}
\hline Regulatory & $\begin{array}{l}\text { - Determines norms and standards for higher education } \\
\text { institutions, the equivalence of qualifications } \\
\text { between institutions, credit accumulation and transfer } \\
\text { procedures. } \\
\text { - } \\
\text { Registers, licenses, and/or accredits new and existing } \\
\text { public/private tertiary institutions. } \\
\text { - Accredits new and/or existing academic programs of } \\
\text { public and/or private institutions. }\end{array}$ \\
\hline Distributive & $\begin{array}{l}\text { - Determines budget allocations for tertiary institutions } \\
\text { and/or the sector as a whole. } \\
\text { - Distributes financial resources from the state to } \\
\text { institutions, units or individuals in the sector. } \\
\text { - Monitors expenditure at both institutional and sectorial } \\
\text { levels. }\end{array}$ \\
\hline Monitoring & $\begin{array}{l}\text { - Collects and analyzes system and institutional level } \\
\text { data, including the development of performance } \\
\text { indicators. } \\
\text { Tracks developments and trends in the system as well } \\
\text { as performance quality of institutions against the } \\
\text { norms and standards set for the sector or against stated } \\
\text { national goals or system targets. }\end{array}$ \\
\hline Advisory & $\begin{array}{l}\text { - Provides expert and research based advice to } \\
\text { policymakers and other tertiary education leadership } \\
\text { in government and institutions, either proactively or } \\
\text { reactively in response to specific requests. } \\
\text { - Comments on or formulates draft policies on behalf of } \\
\text { the ministry responsible for tertiary education. } \\
\text { - Provides advice/ recommendations to the relevant } \\
\text { body on the licensing and accreditation of tertiary } \\
\text { institutions and that of their programs. }\end{array}$ \\
\hline Coordination & $\begin{array}{l}\text { - } \begin{array}{l}\text { Enables interactions between key stakeholders and } \\
\text { policy spheres. }\end{array} \\
\text { - } \begin{array}{l}\text { Promotes the objectives of tertiary institutions or the } \\
\text { sector to the market and within government itself. }\end{array} \\
\text { - } \quad \text { Plans strategically the financing of tertiary education. } \\
\text { - Develops data and knowledge flows between different } \\
\text { system-level governance roles. }\end{array}$ \\
\hline
\end{tabular}

Source: Bailey (2014) 
As will later be shown, norms, standards, and national goals formulated by the Council are too general and insufficiently context-specific. This notwithstanding, it is important to note that the Council grapples with funding for conducting research, and has difficulties sometimes in asserting its autonomy and independence (freedom from political interference by the state) (Bailey, 2014, p. 26).

\section{The authority of the National Accreditation Board}

The National Accreditation Board of Ghana was established by the Provisional National Defense Council Law (PNDC) 317 of 1993. It was later replaced by the National Accreditation Board Act 744 of 2007 (Bailey, 2014). The mission of the Board, according to its official website, is to provide the best basis for establishing, measuring and improving standards in tertiary education in Ghana. To this end, the Board seeks:

- To provide a systematic and rational basis for establishing, monitoring and improving standards in tertiary education through developing benchmarks for accreditation and quality assurance and ensuring proper operations in tertiary institutions.

- To facilitate the development of accredited public and private tertiary institutions toward the attainment of Presidential Charter.

- To determine the equivalences of both local and foreign tertiary and professional qualifications.

The Board also ensures that its operations for service delivery are guided by the values of professionalism, accountability, responsiveness, integrity, and transparency. For example, in awarding accreditation to a new institution, the Board insists that any person or organization applying to establish a tertiary institution shall be required to follow the procedures set out in its policy documents in order to facilitate the process of accreditation 
and the operation of the institution. It also insists that the applicant institution shall first seek and obtain affiliation to operate under the supervision of a recognized mentoring institution which shall award its certificates before accreditation is granted. Table 2 shows three specific requirements set up by NAB for granting accreditation to an applicant institution. These cover authorization, institutional accreditation, and program accreditation.

Table 2: Requirements for tertiary accreditation by the National Accreditation Board

\begin{tabular}{|c|c|}
\hline \multirow[t]{11}{*}{ Authorization } & A letter of application to the National Accreditation Board (NAB). \\
\hline & $\begin{array}{l}\text { Response from NAB including definition of the various categories } \\
\text { of tertiary educational institutions, within two weeks of receipt of } \\
\text { application. }\end{array}$ \\
\hline & $\begin{array}{l}\text { Choice of name of institution based on } 2 \text { above shall be in consultation } \\
\text { with NAB. }\end{array}$ \\
\hline & Registration of the institution at the Registrar General's Department. \\
\hline & $\begin{array}{l}\text { Purchase, completion and submission of Authorization Questionnaire } \\
\text { (NAB/INFO A.1). }\end{array}$ \\
\hline & Payment of an appropriate fee. \\
\hline & $\begin{array}{l}\text { Institutional visit by the relevant NAB Committee where facilities are in } \\
\text { place at the institution, within } 30 \text { days after receipt of payment. }\end{array}$ \\
\hline & Decision by NAB. \\
\hline & Communication of decision within 30 days of institutional visit. \\
\hline & Application for review of decision, if any, within 30 days of communication. \\
\hline & $\begin{array}{l}\text { Communication of Board's decision on the review application within } 14 \\
\text { days after the next immediate Accreditation Committee meeting acting } \\
\text { on behalf of the Board. }\end{array}$ \\
\hline
\end{tabular}


Coker, W./ The governmentality of journalism education in Ghana

\begin{tabular}{|c|c|}
\hline & $\begin{array}{l}\text { - Proof of affiliation to be provided before further processing for } \\
\text { accreditation. } \\
\text { - } \quad \text { Purchase, completion, and submission of institutional accreditation } \\
\text { questionnaire (NAB/INFO A.2) } \\
\text { - } \quad \text { Payment of an appropriate fee. } \\
\text { - Institutional visit by the relevant NAB Committee within } 30 \text { days } \\
\text { - } \quad \text { Vister receipt of an application the Board considers complete } \\
\text { - } \quad \text { within } 30 \text { days after the Committee's visit. } \\
\text { - Communication of NAB's decision within } 90 \text { days of the } \\
\text { Committee's visit and proof of affiliation (See NAB Guidelines for } \\
\text { Affiliation). } \\
\text { Application for review, if any, within } 30 \text { days of communication. }\end{array}$ \\
\hline $\begin{array}{l}\text { Program } \\
\text { accreditation }\end{array}$ & $\begin{array}{l}\text { - Purchase, completion and submission of relevant NAB } \\
\text { questionnaire on program accreditation (NAB/INFO A.3). } \\
\text { - } \\
\text { Payment of an appropriate fee. } \\
\text { Composition of program accreditation panel by the Board and } \\
\text { assessment of program(s) offered/to be offered within } 60 \text { days on } \\
\text { receipt of an application the Board considers complete including } \\
\text { payment of an application fee. } \\
\text { - Submission of panel assessment reports to NAB within } 14 \text { days of } \\
\text { panel visit. } \\
\text { - Submission of panel report(s) to the institution for comments within } \\
\text { 14 days upon receipt of report(s). } \\
\text { Response to panel report(s) by the institution to NAB. } \\
\text { Reaction of panel chairperson to the comments on the report by } \\
\text { the institution within } 30 \text { days on receipt of institution's comments. } \\
\text { - } \quad \text { Recommendation of accreditation committee to the Board at its next } \\
\text { immediate meeting upon receipt of panel chairperson's reaction to } \\
\text { institution's comments. } \\
\text { Decision by Board on the recommendation of the accreditation } \\
\text { committee at the next immediate Board meeting. } \\
\text { Communication of decision within } 14 \text { days after the Board's } \\
\text { decision. } \\
\text { Application for review, if any, within } 30 \text { days of communication of } \\
\text { the Board's decision. }\end{array}$ \\
\hline
\end{tabular}

Source: National Accreditation Board (2011)

Legon Journal of the Humanities 29.1 (2018) 
In ensuring that all accredited institutions meet normative standards set up by the Board, NAB undertakes a review of the institutions at least once every five years. This requirement, according to the Board, provides an opportunity for both the institution and the Board to evaluate the performance of a particular institution with respect to the satisfaction of threshold quality standards and growth. The Board does so by ensuring that an accredited institution submits a self-evaluation report detailing the institution's vision and mission statements, organization and governing bodies, academic and non-academic staff, number of colleges/faculties/schools, programs of study and program details. For example, with respect to program details, the Board requires that an institution seeking reaccreditation must submit the following items:

- Program accreditation and re-accreditation history;

- Students' enrolment history (for the past five (5) years or since last accreditation);

- Number of academic staff (emphasizing full-time, parttime and visiting by ranks for the past five (5) years or since last accreditation);

- Different sessions/mode for the running of programs (e.g., evening sessions, weekend sessions, distance learning option, sandwich sessions, regular sessions).

Faculty evaluation takes into account the mode of employment (full/part time), highest qualification and year obtained, area of specialization, rank (tutor/lecturer/senior lecturer/associate professor/professor) as well as years of experience in teaching and research. For example, each faculty member is required to provide details of published work in the last five years including research publications, books, technical reports and international conference presentations/papers. Pendell (2012) notes that faculty evaluation processes have serious professional outcomes for faculty members and serious legal ramifications for the university if it is not properly 
done. She suggests that best practices in faculty evaluation are important for protecting communication faculty, department chairs and their universities. Her seven-point recommendation points to the need for the evaluation of communication faculty to be clearly defined and specific, systematic, regular, and goal-driven.

The Board also requires that all funded institutions provide details on student and academic affairs. It obliges institutions to make available statistics about student populations, admission procedures and requirements and mandatory courses. It is important to note that the National Accreditation Board also ensures that institutions seeking reaccreditation welcome students' participation, dissent and/or complaints, as well as make room for engagement in co-curricular/extra-curricular activities (see the World Bank report for a comprehensive discussion on higher education in Africa in Materu, 2007; cf. Sanya, 2013). My observation over the last decade (as both a student and faculty member) indicates that students' investment in extracurricular activities rarely add to their credits. Activities such as sports, dance competition and debates are often difficult to evaluate by faculty as part of general assessment in many public universities in Ghana. It must also be noted that some students do not participate in extracurricular activities for narrow reasons. In short, there is no agreed upon framework for assessing extra-curricular activities students engage in in a number of public universities in Ghana.

The next strand of the paper unmasks hidden ideologies and values embedded in the curriculum of the Bachelor of Arts Communication Studies of the University of Cape Coast.

\section{An evaluation of UCC's Bachelor of Arts in Communication Studies program}

The undergraduate communication studies program of UCC was designed in 2010 by faculty to improve and expand the university's range of disciplines. Initially conceived as a mass communication program, it specializes in print and broadcast journalism as well as public relations and advertising. The program is the result of the input by the Academic Board of the university, 
recommendations from media practitioners and other competent institutions, key among which is the National Accreditation Board (NAB), the final arbiter. As already noted, the accreditation of new programs is a difficult task. To be sure, it involves a great deal of rhetorical aptitude. The designers of the curriculum had to persuade $\mathrm{NAB}$ about the rationale, employment prospects, as well as the target group of the program (e.g., high school graduates, personnel from the Ghana Education Service, polytechnics and colleges of education). As I have already discussed, these requirements are important for determining whether the goals set by the department meet the development agenda of the state.

Planners of the curriculum argued for accreditation on two grounds: the need to train more skilled media practitioners and expand students' job prospects. They held that a rigorous training in communication in contemporary Ghana was urgent to reflect changing trends in the media landscape. Faculty maintained that it was important to augment the numerical strength of media personnel in the country because of the deregulation of the airwaves and the consequent proliferation of FM radio stations and privately-owned television outlets. According to them, there has arisen the need for a training opportunity for persons who have drifted into journalism more out of enthusiasm and the pressure to find a means of living than professional commitment. They argued that the envisaged program would enable practicing media professionals to go for regular refresher courses. This effort, they said, was important to keep media practitioners informed of the continually changing trends in the media landscape. The training was thus envisaged to create employment opportunities for students and media professionals to take up positions in the media and raise media practice in Ghana to acceptable standards that can compare with best practices around the world. For these reasons, the program seeks to meet four main objectives:

1. To train human resource in communication studies.

2. To equip students with knowledge of current trends in 
communication studies.

3. To equip students with theoretical resources and skills for doing self-reflection of their practices as communication practitioners, and

4. To equip students with skills that will enable them to engage in research in communication studies (EduBuandoh, 2016, personal communication). Even though the intentions of the designers of the newly accredited program were noble as they sought ways to create job opportunities for their students and enhance communication systems in the country, it may be helpful to note that this effort, nonetheless, satisfies the developmentalist agenda (Zeleza, 2003). A closer look at the four-pronged objective above reveals that the focus of the program is on the acquisition of skills which, the designers hope, can "equip" graduates to attain selfdevelopment and help in the process of nation-building. In other words, the emphasis of the program from its early conception appears to be utilitarian in scope. Table 3 is a sample of the first two years of the undergraduate communication program in the university under review. 
Coker, W./ Legon Journal of the Humanities 29.1 (2018)

Table 3.1: A sample of a four-year Bachelor of Arts in Communication Studies First Year

\begin{tabular}{|c|c|c|c|c|c|c|c|}
\hline & SEMESTER. I & & & & SEM. II & & \\
\hline $\begin{array}{l}\text { Course } \\
\text { Code }\end{array}$ & Course Title & & Credits & Course Code & Course Title & & Credit \\
\hline $\begin{array}{l}\text { CMS } \\
101\end{array}$ & $\begin{array}{l}\text { Introduction to } \\
\text { Mass } \\
\text { Communication }\end{array}$ & Core & 3 & $\begin{array}{l}\text { CMS } \\
102\end{array}$ & $\begin{array}{l}\text { History o f } \\
\text { the Ghanaian } \\
\text { Mass } \\
\text { Media }\end{array}$ & Core & 3 \\
\hline $\begin{array}{l}\text { CMS } \\
105\end{array}$ & $\begin{array}{l}\text { New } \\
\text { Communication } \\
\text { Technologies }\end{array}$ & Core & 3 & $\begin{array}{l}\text { CMS } \\
104\end{array}$ & $\begin{array}{l}\text { Introduction to } \\
\text { Writing } \\
\text { for the } \\
\text { Mass Media }\end{array}$ & Core & 3 \\
\hline $\begin{array}{l}\text { CMS } \\
105 \mathrm{~A}\end{array}$ & $\begin{array}{l}\text { Communicative } \\
\text { Skills }\end{array}$ & Core & 3 & ENG 105B & $\begin{array}{l}\text { Communica- } \\
\text { tion Studies }\end{array}$ & Core & 3 \\
\hline AFS & African Studies & Core & 2 & ASP & African Studies & Core & 1 \\
\hline $\begin{array}{l}\text { IRC } \\
101\end{array}$ & $\begin{array}{l}\text { In formation } \\
\text { Retrieval }\end{array}$ & Core & 1 & $\begin{array}{l}\mathrm{LED} \backslash \mathrm{L} \\
\mathrm{ESS} \backslash \mathrm{LS} \mathrm{C}\end{array}$ & Liberals & & 2 \\
\hline Subj B & & Core & 3 & Subject B & & & 3 \\
\hline Subj C & & Core & 3 & Subject C & & & 3 \\
\hline Total & & & & & & & \\
\hline
\end{tabular}

Source: Faculty of Arts, UCC (2013-2016) Brochure 
Coker, W./ The governmentality of journalism education in Ghana

Table 3.2: A sample of a four-year Bachelor of Arts in Communication Studies Second Year

\begin{tabular}{|c|c|c|c|c|c|c|c|}
\hline \multicolumn{4}{|c|}{ SEMESTER I } & \multicolumn{4}{|c|}{ SEMESTER II } \\
\hline $\begin{array}{l}\text { Course } \\
\text { Code }\end{array}$ & Course Title & & Credit & $\begin{array}{l}\text { Course } \\
\text { Code }\end{array}$ & Course Title & & Credit \\
\hline $\begin{array}{l}\text { CMS } \\
202\end{array}$ & $\begin{array}{l}\text { Theories of } \\
\text { Comm. }\end{array}$ & Core & 3 & $\begin{array}{l}\text { CMS } \\
210\end{array}$ & $\begin{array}{l}\text { Foundations } \\
\text { of Comm. } \\
\text { Research }\end{array}$ & Core & 3 \\
\hline $\begin{array}{l}\text { CMS } \\
203\end{array}$ & $\begin{array}{l}\text { Feature } \\
\text { Writing } \\
\text { (Print) }\end{array}$ & Core & 3 & $\begin{array}{l}\text { CMS } \\
209\end{array}$ & $\begin{array}{l}\text { Editing and } \\
\text { Graphics of } \\
\text { Comm. }\end{array}$ & Elective & 3 \\
\hline $\begin{array}{l}\text { CMS } \\
204\end{array}$ & $\begin{array}{l}\text { Foundations } \\
\text { of } \\
\text { Broadcasting } \\
(\mathrm{R} / \mathrm{TV})\end{array}$ & Elective & 3 & $\begin{array}{l}\text { CMS } \\
215\end{array}$ & $\begin{array}{l}\text { Radio } \\
\text { Program Writing } \\
\text { Prod. }\end{array}$ & Elective & 3 \\
\hline $\begin{array}{l}\text { CMS } \\
208\end{array}$ & $\begin{array}{l}\text { Introduction } \\
\text { to advertising } \\
\text { (PRAD) }\end{array}$ & Elective & 3 & $\begin{array}{l}\text { CMS } \\
206\end{array}$ & $\begin{array}{l}\text { M a r k e t i n } \mathrm{g} \\
\text { Foundations for } \\
\text { Public Relations } \\
\text { and Advertising }\end{array}$ & Elective & 3 \\
\hline Subj B & & Core & 3 & Subj B & & Core & 3 \\
\hline Subj C & & Core & 3 & Subj C & & Core & 3 \\
\hline Total & & & 18 & Total & & & 18 \\
\hline
\end{tabular}

Source: Faculty of Arts, UCC (2013-2016) Brochure

The heavy emphasis on skills development in the structure of this communication curriculum is indicative of the crisis many universities across cultures are grappling with. It is a crisis that betrays the self-critical nature of university education as universities are coerced by the panoptic apparatuses of the state to produce human labor in the service of the economy. In "Truth, power, 
intellectuals, and universities," Coker, W./ Legon Journal of the Humanities 29.1 (2018) Bert (2011) cautioned that university programs are currently controlled by the master discourses of economics, corporatization and bureaucratization. What this means for program administrators and faculty of communication departments is that they can offer little resistance as their practices (e.g., roles, pedagogy, terms and conditions of service and grading schemes) are monitored by regimes of power. The essence, Berth (2011) notes, is to determine whether their professional conduct is in tandem with development objectives. For example, apart from seminars in African Studies and Liberals, all the courses in the first and second years of the communication program of UCC expose students to a somewhat skill-based education. A similar claim can be made of the third and final years of the program except that the curriculum recognizes that an exposure to the geopolitics of media systems in Africa and media law, for example, are crucial for students to develop critical awareness of their field of study. This state of affair, in my view, is the result of the systems of control set in place by state regulatory agencies to ensure that students are given "employable" skills.

It may, however, be helpful to note that a fixation on skills makes communication training somewhat instrumentalist in scope. A consequence of this focus is that often both faculty and students see communication education as a means to an end. This is perhaps the result of a century-old pedagogy of quantitative functionalist sociology championed by Paul F. Lazarsfeld. In his book, The Invention of communication (1996), the French sociologist Armand Mattelart warns us against a pedagogy that is putatively media-tropic. According to Mattelart (1996), a mediacentered education "engenders a reductive vision of the history of communication" (p. x) because it blinds us to the realization that communication is much more than the study of media systems as some communication programs would have us believe. He goes further to argue that communication pedagogy must arouse in individuals the idea that communication is an ideology and "a system of thought and power and as a mode of government" (p. xi). His book is a classic articulation of how systems of technologies 
such as telecommunications, railway systems and time were used and controlled by the world's powerful nations like the United States, France and England to maintain hegemony and dominance during the first and second world wars.

The idea that a technical education is the goal of modernity may thus be a myth. For while it guarantees conquest over the conditions of human existence, an instrumentalist view of communication education alone is inadequate. According to Heidegger (1993), too much focus on technology as doing (techné) rather than as revealing (alētheia) or enframing (Gestell), for instance, can lead humanity to disastrous consequences. Technology could make individuals become uncritical of technology itself, and what it does or makes (Gegenstand). Technology, Heidegger (1993) suggested, is, therefore, in a lofty sense ambiguous. It can be a good servant, and yet a bad master. The internet has wrought such a positive influence on trade and industry, transportation (maritime, rail, aviation, etc.), medicine, education and almost all sectors of interpersonal relationships. Yet we cannot discount how the technology is being abused in the hands of the wily for personal gains. So, on the one hand, technology is a saving power; on the other hand, it is a leviathan. Excessive emphasis on the technical perspective of communication education could make it lose its critical luster. I join Odhiambo et al. (2002) in proposing that the training in Africa should involve seminars in critical theory, interpersonal and intercultural communication and ethics rather than the narrow focus on media and journalism which have dominated the training in communication education for far too long in sub-Saharan Africa.

\section{Recommendations}

The incorporation of critical theory into journalism education in Ghana is strongly recommended. Critical theory writ large is a critique of society. It is an approach that examines society in a dialectical way by deconstructing political economy, domination, exploitation and ideologies. Critical theories such as postcolonialism, critical political economy, cultural studies 
and poststructuralism emphasize the discursive nature of communicative phenomena. They recognize that the many ways individuals tend to narrate their stories or the artifacts they produce as evidence of their communication skills are not disinterested; they are culturally, ideologically and politically motivated. Introducing critical communication theories in the curricula of journalism education is, therefore, crucial for empowering students to unmask formal and informal institutional practices that enable, shape and perpetuate inequality, dominance, power asymmetry and hegemony in society. As Craig (1999, p. 149) notes, a critical tradition of communication studies must confirm "that reflective discourse and communication theory itself have important roles to play in our everyday understanding and practice of communication." Its goal is to transform society in positive ways.

For instance, Edward Said's postcolonial theory is of immense importance to media studies. In his work "Islam as news", Said (1980) extends the thesis he develops in his magnum opus Orientalism (1979) and provides evidence of Western media's deliberate distortions of Islam for politico-economic ends. In his view, the media and the West not only license patent inaccuracy but also express ethnocentrism, cultural and racial hatred for the East. This, he argues, is caused by two main forces: the making of an image and its use to create a monolithic worldview of the East. He observes that the West's understanding of the East is completely distorted and often based on caricatures and exaggerations of evil, masqueraded in terrorism, anarchism, oil turmoil, and misrepresentation. Writing within the context of the geopolitics of expansionism between the forces of the US and former world empires France and Britain, Said notes that the US relies often on skewed media reportage to sustain its interest in the East. Interestingly, the same media, he writes, looks favorably on the activities of Israel in the same region because Israel is America's ally. It is this myth, Said laments that the Western media turns into realities by showing frightening mobs, the concentration on Islamic punishments and barbarism as justifications for occupying the East. 
Coker, W./ The governmentality of journalism education in Ghana

Critical theory such as Said's postcolonial theory is of mammoth importance to students of journalism and media studies in subSaharan Africa in order to enable them to understand the hidden and taken-for-granted inequalities in society. The essence of this type of education, Splichal (2008) notes, enables students to "question existing conditions in terms of their historical preconditions and future possibilities" (p. 20).

Journalism educators need to also appreciate the aesthetics of transculturalism at work in the twenty-first century. Transculturalism is a way of life in which some individuals find ways to transcend their previous cultures in order to explore and examine other cultures (Grunitzky, 2004 cited in Hepp, 2015, p. 1). It is made possible by globalization and mediatization. Because this epoch continues to be marked by cultural flows, mobility, and transnationalism (Appadurai, 1996), it is important that such institutional practices as pedagogy, theory, assessment practices, and curriculum development that shape the work of communication educators are constantly viewed as transcultural. Such recognition is important so that program administrators and governmental agencies may accommodate change, adaptation, and diversity through constant negotiation, transparency, and self-reflexivity. Transcultural competence in professional journalistic practice is thus the competence required to make sense of the implications values from other cultures have on institutional practices. What gets accepted eventually as normative ways of understanding journalism education in differing contexts is a function of how they are understood by actors in specific institutions and the nature of quality assurance systems they enable.

\section{Conclusion}

In the context of Ghana, quality assurance systems in journalism education are fraught with a number of challenges. One difficulty is that it is not discipline-specific. Because national councils and state regulatory boards that superintend professional practices in the academy focus more on accountability to government than on the disciplines, the requirement takes away attention from the 
fact that quality assurance of the many professional communities constituting the academy needs to be discipline-specific. To be sure, this is a daunting task because quality assurance protocols are onerous to stakeholders. However, my call to develop discipline-based quality assurance processes derives from the idea that academic communities, the epistemologies that shape their work, and the texts they produce can be best "measured" within their own material modes of production. The African Council for Communication Education (ACCE), for instance, can be consulted by the regulatory bodies of member states to map out standards specific to the field.

Further, quality assurance in Ghana is insufficiently transcultural. In view of the increasing relevance of globalization, global outsourcing of labor (Smith, 2012), and growing graduate mobility (Brady \& José, 2009), the emergence of a set of global standards for understanding professional practices and students' capabilities is desirable. In the context of journalism education, what standards, norms, and criteria will reflect the quality of an international journalism education? Though the National Council for Tertiary Education has also established several links with institutions across the globe such as Carnegie Corporation of New York; Japan International Cooperation Agency (JICA); Netherlands Organization for International Cooperation in Higher Education (NUFFIC) and The World Bank, increased partnerships among organizations such as the Association of American Colleges and Universities (AAC\&U), Association of African Universities (AAU), and Association of West African Universities (AWAU) will be very useful. For example, how will ACCE partner the International Communication Association (ICA) and the National Communication Association (NCA) of the United States and the Association of Communication Administrators (ACA) to achieve the goal of global education, citizenship, and development?

Only time will tell how the panoptic gaze of state apparatuses will be reconfigured. As public universities on the African continent have begun to adopt a market model, it is becoming clear that a 
number of African states are renegotiating their terms of institutional control (Makungu, 2009). The government of Ghana, for example, "has charged the universities to come out with strategies that would make the universities generate their own funds to supplement what the government offers for running the universities, and also place the universities on par with businesses on the world market" (EduBuandoh, 2010, 59). This marketization discourse has led publicfunded universities in Ghana to formulate their own corporate strategic plans. The move is a response to the World Bank's (2010) blueprint for improving on the financing of higher education in Africa. The context directing journalism education in Ghana is thus clear: it is instrumentalist. It serves the purposes of the state. Although useful for promoting a developmental agenda, this type of education can hardly be "truly decolonized, autonomous," and "committed to the pursuit of intellectual excellence" because it does the bidding of its paymasters (Zeleza, 2003, p. 113). Some scholars have thus called for a shift in paradigm (Taylor et al, 2004). This shift in journalism education is important for constantly engaging the critical edge of the training in order to engender in students a heightened sense of responsibility and reflexivity toward the people they intend to serve. 
Coker, W./ Legon Journal of the Humanities 29.1 (2018)

\section{References}

Ansu-Kyeremeh,K. (2014). Critically 'trending' approaches to communication theory and methods of inquiry in Ghana. In S. Agyei-Mensah, J. A. Aryee \& A. O. Oduro (Eds.), Changing perspectives on the social sciences in Ghana (pp. 221-238). New York: Springer.

Appadurai, A. (1996). Modernity at large: Cultural dimensions of globalization. Minneapolis: University of Minnesota Press.

Alridge, M., \& Evetts, J. (2003). Rethinking the concept of professionalism: The case of journalism. The British Journal of Sociology, 54, 547-564.

Attuahene, F., \& Owusu-Ansah, A. (2013). A descriptive assessment of higher education access, participation, equity and disparity in Ghana. Sage Open, 3 (3), 1-16.

Bailey, T. (2014). The role and functions of higher education councils and commissions in Africa: A case study of the Ghana National Council for Tertiary Education. Wynberg, SA: Centre for Higher Education Transformation (CHET).

Bert, O. (2011). Truth, power, intellectuals, and universities. In G.Walmsley (Ed.), African philosophy and the future of Africa (Vol. 14, pp. 23-46). Washington, DC: The Council for Research in Values and Philosophy.

Boafo, S. T. K., \& Wete, F. (2002). Introduction. In S. T. K. Wefe (Ed.), Communication training in Africa: Model curricula. UNESCO: Panoply.

Boafo, S. T. K. (1988). Journalism profession and training in sub-Saharan Africa: A case study of Ghana. Africa Media Review, 2 (3), 56-74.

Bossio, D. (2011). Defining journalistic professionalism within the higher education system. International Journal of the Humanities, 8 (10), 5565.

Brady, A., \& José, L. (2009). Writing for an international audience in a US technical communication classroom: Developing competence to communicate knowledge across cultures. Nordic Journal of English Studies, 8 (1), 41-60.

Brandt, D. (1998). Sponsors of literacy. College Composition and Communication, 49(2), 165-185.

Chamberlain, J. M. (2014). Governmentality. In B. A. Arrigo (Ed.), Encyclopaedia of criminal justice ethics (pp. 395-397). Thousand Oaks, CA: Sage.

Craig, R (1999). Communication theory as a field. Communication Theory, 9 (2), 119-161.

Diedong, A. (2008). Establishing journalistic standards in the Ghanaian press. African Communication Research, 1 (2), 206-232.

Edu-Buandoh, D. F. (2016). Personal communication: Interview on the landscape of communication education in Ghana. University of Cape Coast, Cape Coast, Ghana. April, 24.

Edu-Buandoh, D. F. (2010). Discourse in institutional administration of public universities in Ghana: A shift towards a market paradigm? Nebula, 7 (3), 59-77. 
Ewell, P. (2010). Twenty years of quality assurance in higher education: What's happened and what's different? Quality in Higher Education, 16 (2), 173-175.

Faculty of Arts, University of Cape Coast. (2013-2016). Faculty brochure. Cape Coast: University of Cape Coast Press.

Foucault, M. (1997). The birth of biopolitics. In P. Rabinow (Ed.), Michel Foucault, ethics: Subjectivity and truth (pp. 73-79). New York: The New Press.

Foucault, M. (1995). Discipline and punish: The birth of the prison (A. Sheridan, Trans.). New York: Vintage Books. (Original work published 1975)

Gondwe, M., \& Walenkamp, J. (2011). Alignment of higher education with the needs of the local labour market: The case of Ghana. The Hague: Netherlands Organization for Cooperation in Higher Education, NUFFIC.

Goodman, R. S., \& Steyn, A. (2017). Global journalism education in the 21st century:Challenges and innovations. Austin, TX: Regent Press.

Gorman, B. B. (2012). Governmentality in higher education: A critical analysis of the national survey of student engagement (NSSE). (PhD dissertation). Michigan Technological University, Michigan, USA.

Heidegger, M. (1993). The question concerning technology. Basic writings (pp. 307-342). (D. F. Krell, Trans.). New York: Harper Collins. (Original work published 1964)

Hepp, A. (2015). Transcultural communication. Malden, MA: Wiley Blackwell.

Houston, D., \& Paewai, S. (2013). Knowledge, power and meanings shaping quality assurance in higher education: A systemic critique. Quality in Higher Education, 19 (3), 261-282.

James, S. L. (1990). Development of indigenous journalism and broadcast formats: Curricular implications for communication studies in Africa. Africa Media Review, 4 (1), 1-14.

Makungu, K. M. (2009). Designing an MA program in communication for development: The experience of the University of Zambia. African Communication Research, 2 (2), 253-270.

Mattelart, A. (1996). The invention of communication (S. Emanuel, Trans.). Minneapolis: University of Minnesota Press. (Original work published 1996)

Materu, P. (2007). Higher quality assurance in sub-Saharan Africa. Washington, DC: The World Bank.

Murphy, M., \& Scotton, J. F. (1987). Dependency and journalism education in Africa: Are there alternative models? Africa Media Review, 1 (3), 1135.

National Accreditation Board, Ghana (2011). Roadmap to accreditation. http://www.nab.gov.gh/2014-08-13-14-37-14/accreditation-documents

National Council for Tertiary Education. (2011). Annual report 2009. Accra: National Council for Tertiary Education. 
Odhiambo, L. O., Boafo, S. T. K., Aznar, A., McClain, J., \& Sy, C. (2002). Communication education and training in the 21st century: The African context. In S. T. K. Boafo (Ed.), Communication training in Africa: Model curricula (pp 7-14). UNESCO: Panoply.

Ogundimu, F. F., Oyewo, O. Y., \& Adegeke, L. (2010). West African journalism education and the quest for professional standards. Ecqui Novi: African Journalism Studies, 1 (2), 191-197.

Pendell, S. (2012). Best practices in faculty evaluation. Journal of the Association for Communication Program Administration, 31 (2), 146-147.

Peters, M. A., Besley, A. C., Olssen, M, Maurer, S., \& Weber, S. (2009). Governmentality studies in higher education. Boston: Sense Publishers.

Said, E. (2000). Islam as news. In M. Bayoumi (Ed.), The Edward Said reader (pp. 169-194). New York: Vintage Books. (Original work published 1980)

Said, E. (1979). Orientalism. New York: Vintage Books. (Original work published 1978)

Sanya, B. C. (2013). Quality assurance of teacher education in Africa. Addis Ababa: International Institute for Capacity Building in Africa

Skjerdal, T. S. (2012). The three alternative journalisms of Africa. International Communication Gazette, 74 (7), 636-654.

Smith, B. Q. (2012). Reading and writing in the global workplace: Gender, literacy, and outsourcing in Ghana. New York: Lexington Books.

Somuah, C. (2008). World Bank/MOESS consultancy assignment on tertiary education. Washington, DC: World Bank.

Splichal, S. (2008). Why be critical? Communication, Culture and Critique, 2, 20-30.

Taylor, D. S., Nwosu, P. O., \& Mutua-Kombo, E. (2004). Communication studies in Africa: The case for a paradigm shift for the 21st century. Africa Media Review, 12 (2), 1-23.

World Bank (2010). Financing higher education in Africa. Washington, DC: World Bank.

Zeleza, P. T. (2003). Rethinking Africa's globalization: The intellectual challenges (vol. 1). Trenton, NJ: Africa World Press. 